\title{
Temporal Requirement of the Protein Tyrosine Phosphatase Shp2 in Establishing the Neuronal Fate in Early Retinal Development
}

\author{
Zhigang Cai, ${ }^{1}$ Gen-Sheng Feng, ${ }^{2}$ and Xin Zhang ${ }^{1}$ \\ ${ }^{1}$ Department of Medical and Molecular Genetics, Stark Neuroscience Institute, Indiana University School of Medicine, Indianapolis, Indiana 46202, and \\ ${ }^{2}$ Department of Pathology, School of Medicine, and Section of Molecular Biology, Division of Biological Sciences, University of California, San Diego, \\ La Jolla, California 92093
}

FGF signaling is critical in the development of the vertebrate retina, which differentiates in a wave-like pattern similar to that found in the Drosophila eye. In this study, we investigated the mechanism of FGF signaling in vertebrate eye development by identifying Shp2, a protein tyrosine phosphatase, as a novel factor in orchestrating retinal morphogenesis. Using a series of $\operatorname{Sh} p 2$ conditional mutants, we have shown that $S h p 2$ is specifically required for the initiation of retinal neurogenesis but not for the maintenance of the retinal differentiation program. By mosaic deletion of $\operatorname{Sh} p 2$, we further demonstrated that $\operatorname{Sh} p 2$ ablation did not prevent the spreading of the retinal differentiation wave. Shp2 instead controls the patterning of the optic vesicle by regulating the retinal progenitor factors and cell proliferation. In ex vivo culture models and genetic rescue experiments, we showed that $\operatorname{Sh} p 2$ acts downstream to FGF signaling in retinal development and that it can be functionally substituted by activated Ras signaling. Together, these results demonstrate that Shp2 mediates FGF-Ras signaling to control retinal progenitor cell fate.

\section{Introduction}

FGF signaling is required for both early patterning of the optic vesicle and the subsequent retinal differentiation wave. When the chick optic vesicle was stripped off the surface ectoderm (the source of Fgf1 and Fgf2), it developed into a mixture of neural and pigmented cells unless FGF-expressing fibroblasts or viruses were added to the optic vesicle culture (Pittack et al., 1997; Hyer et al., 1998). Numerous explant culture studies have also shown that ectopic FGF expression could transform the retinal pigmented epithelia (RPE) into a neural retina (Park and Hollenberg, 1989; Guillemot and Cepko, 1992; Zhao et al., 1995; Pittack et al., 1997). This appeared to be mediated by Ras-mitogen-activated protein kinase (MAPK) signaling, because similar RPE transformation could be induced by expression of constitutively MEK1 (activated MAP kinase kinase 1), an MAP kinase activator, or activated Ras (Zhao et al., 2001; Galy et al., 2002). Additional explant culture experiments using FGF1/2-soaked beads demonstrated that FGF signaling suppressed the expression of the RPE transcription factor Mitf but activated the neural retinal transcription factor Chx10, setting up the boundary of RPE and the

Received Aug. 23, 2009; revised Jan. 12, 2010; accepted Feb. 10, 2010.

This work was supported by National Institutes of Health Grants EY017061 and EY018868 (X.Z.). We thank Drs. Milan Jamrich, Yasuhide Furuta, Nadean Brown, Peter Gruss, Ruth Ashley-Padan, Bridget Hogan, Douglas Forrest, Lin Gan, Jane Johnson, Roderick R. McInnes, Valerie Wallace, Minh-Thanh T. Nguyen, Tom Glaser, Naoki Takahashi, and Guillermo Oliver for mice and reagents, Drs. Kenneth White and Emily Farrow for help with immunohistochemistry, Kristina Hertzler for critical reading of this manuscript, and members of the Zhang laboratory for discussions.

Correspondence should be addressed to Xin Zhang, Department of Medical and Molecular Genetics, Stark Neuroscience Institute, Indiana University School of Medicine, Indianapolis, IN 46202. E-mail: xz4@iupui.edu.

DOI:10.1523/JNEUROSCI.4364-09.2010

Copyright $\odot 2010$ the authors $\quad 0270-6474 / 10 / 304110-10 \$ 15.00 / 0$ neural retina in the optic vesicle (Nguyen and Arnheiter, 2000; Horsford et al., 2005). FGF signaling may also drive the vertebrate retinal differentiation wave in eye development. Pharmacological inhibition of FGF signaling significantly retarded the movement of the retinal ganglion cell differentiation wave in chick embryos, whereas exogenous $F g f 8$ appeared to substitute for midline signaling emanating from the optic stalk to initiate the retinal ganglion cell differentiation wave in zebrafish (McCabe et al., 1999; Martinez-Morales et al., 2005). Additional studies showed that zebrafish Fgf3/Fgf8 were required for initiation of retinal neurogenesis, whereas Fgf19 was required for its subsequent progression across the retina (Martinez-Morales et al., 2005; Vinothkumar et al., 2008).

Despite the above evidence in support of the role of FGF signaling in retinal development, other than the modest RPE expansion phenotype in Fgf9 mutants, no other mouse mutations in either Fgfs or Fgfrs showed any retinal developmental defects (Dono et al., 1998; Ortega et al., 1998; Miller et al., 2000; Zhao et al., 2001; Wright et al., 2004). Although it is possible that FGF signaling may function in a species-dependent manner, the potential redundancy among 22 Fgfs and 4 Fgfrs certainly complicates the genetic analysis of FGF signaling in mammalian retinal development. One way to untangle the complexity of FGF signaling in retinal development is to study its downstream mediators. Many receptor tyrosine kinases, including Fgfr, require Shp2 protein-tyrosine phosphatase to attain full activation of MAPK signaling, although the exact mechanism is still unclear (Van Vactor et al., 1998; Feng, 1999). In this study, we have generated retinal specific ablations of Shp2 to study its novel function in retinal development. Our results show that Shp2 signaling is required for the patterning of the neural retina, but this signaling is 


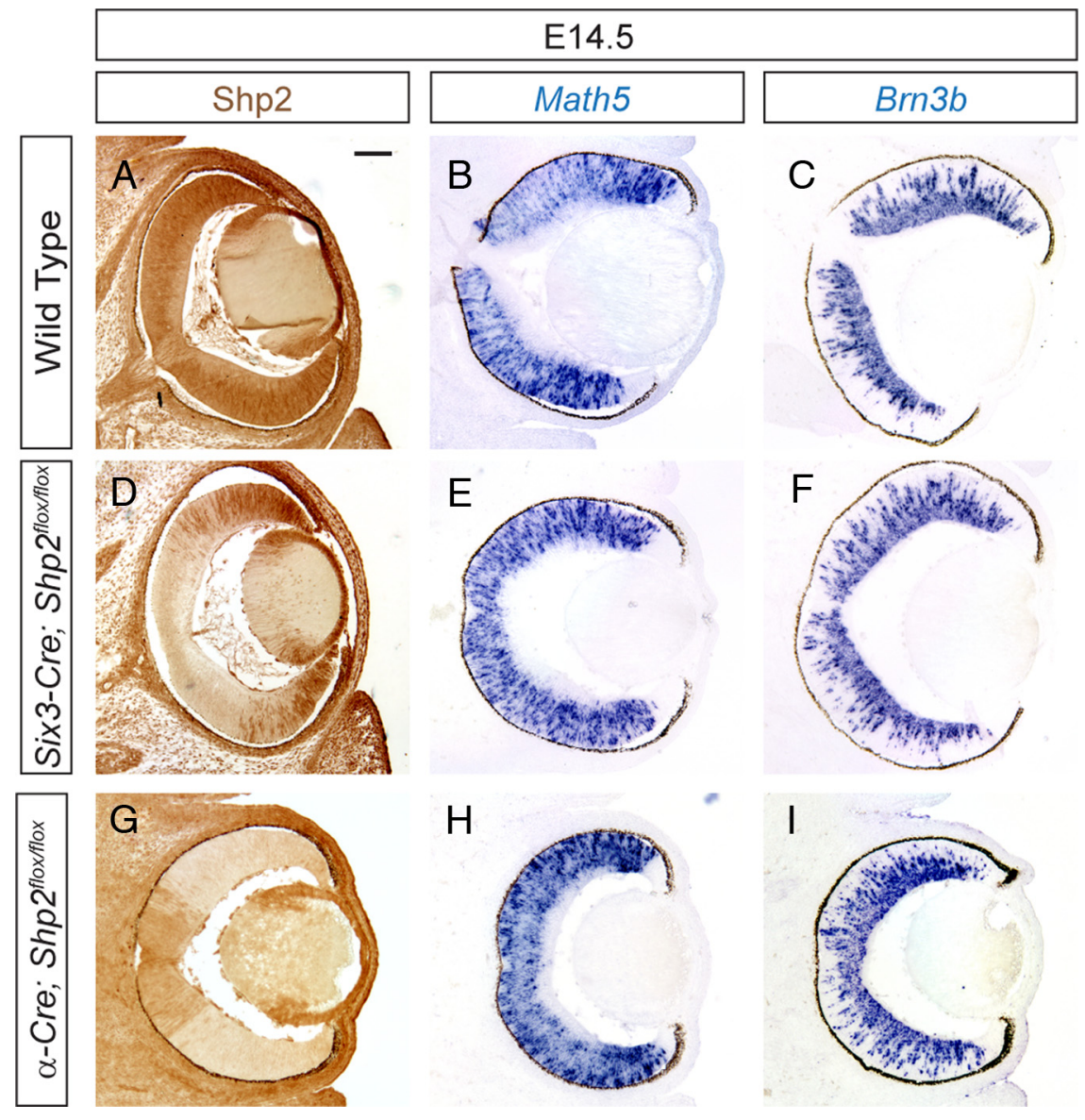

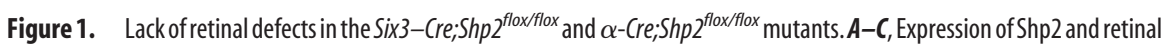
differentiation genes Math5 and Brn3b in wild-type retina at E14.5. D-F, Shp2 was abolished in the center of Six3-Cre;Shp2 $2^{\text {floxfflox }}$ retina, but Math5 and Brn3b expressions remained unaffected. G-I, Shp2 was efficiently depleted in the $\alpha$-Cre;Shp $2^{\text {flox }}{ }^{\text {fllox }}$ peripheral retina, but no changes were observed in Math5 and Brn3b expressions. Scale bar, $100 \mu \mathrm{m}$.

dispensable after the initiation of retinal differentiation. By ex vivo culture and genetic interaction experiments, we further demonstrate that Shp2 controls retinal development by mediating FGF-Ras signaling.

\section{Materials and Methods}

Mice. Shp $2^{\text {flox }}$ mice have been described previously (Zhang et al., 2004). $R x-$ Cre mice were kindly provided by Dr. Milan Jamrich (Baylor College of Medicine, Houston, TX) (Swindell et al., 2006). Six3-Cre mice were kindly provided by Dr. Yasuhide Furuta (M. D. Anderson Cancer Center, Houston, TX) (Furuta et al., 2000). $\alpha$-Cre mice were kindly provided by Drs. Nadean Brown (Children's Hospital Research Foundation, Cincinnati, $\mathrm{OH}$ ), Peter Gruss (Max Planck Institute for Biophysical Chemistry, Göttingen, Germany), and Ruth Ashery-Padan (Tel Aviv University, Tel Aviv, Israel) (Marquardt et al., 2001). LSL-Kras ${ }^{G 12 D}$ mice were obtained from the Mouse Models of Human Cancers Consortium Repository at National Cancer Institute (Tuveson et al., 2004). All mice are maintained in mixed genetic background. All experiments were performed in accordance with institutional guidelines.

Immunohistochemistry. Mouse embryos were staged according to the day the vaginal plug was observed, and somite number was counted for embryonic day 8.5 (E8.5) to E10.5 embryos. The samples were fixed in $4 \%$ paraformaldehyde (PFA) overnight for cryosections or paraffin sections before standard immunohistochemistry was performed as described previously (Pan et al., 2006, 2008). For Shp2 and phosphoextracellular signal-regulated kinase (ERK) staining, we performed the tyramide signal amplification (TSA) procedure as follows (TSA Plus Fluorescein System; PerkinElmer Life and Analytical Sciences). Briefly, cryo- sections were incubated in sub-boiling citrate buffer for $10 \mathrm{~min}$, quenching of peroxidase activity using a $3 \% \mathrm{H}_{2} \mathrm{O}_{2}$ solution in methanol followed, and the sections were blocked in 5\% goat serum in PBS at room temperature for $1 \mathrm{~h}$ and probed with primary antibodies at $4^{\circ} \mathrm{C}$ overnight. The sections were next blocked in TNB blocking buffer (0.1 м Tris- $\mathrm{HCl}, \mathrm{pH} 7.5$, $0.15 \mathrm{M} \mathrm{NaCl}, 0.5 \%$ blocking reagent) before an anti-rabbit HRP secondary antibody was added, and the signal was amplified and detected using TSA fluorescein. The antibodies used were anti-Shp2 (Sc-280; Santa Cruz Biotechnology), anti-phospho-ERK1/2 (catalog \#9101; Cell Signaling Technology) and anti-Cyclin D1 (catalog \#2926; Cell Signaling Technology), anti-Ki67 (catalog \#550609; BD Pharmingen), anti-Islet1 (39.4D5; Developmental Studies Hybridoma Bank), anti-NF165 (2H3; Developmental Studies Hybridoma Bank), and antiPax6 (PRB-278P; Covance). Anti-Ptfla was kindly provided by Dr. Jane E. Johnson (University of Texas Southwestern Medical Center, Dallas, TX) (Hori et al., 2008). Anti-TR $\beta 2$ was kindly provided by Dr. Douglas Forrest (National Institutes of Health, Bethesda, MD) (Ng et al., 2009).

RNA in situ hybridization. RNA in situ hybridization was performed as described previously, and the depletion of Shp2 was always confirmed by Shp 2 immunohistochemistry on adjacent sections (Pan et al., 2008). For triplefluorescent staining, frozen sections were first hybridized with digoxigenin-labeled Fgf15 and fluorescein-labeled Mitf probes, incubated with anti-digoxigenin and anti-fluorescein peroxidase antibodies (Roche Diagnostics), and detected with FITC TSA-plus and cyanine 3 (Cy3) TSA-plus, respectively (PerkinElmer Life and Analytical Sciences). This was immediately followed by Islet 1 antibody staining, detected with a Cy5-conjugated secondary antibody. The following probes were used: Erm (from Dr. Bridget Hogan, Duke University Medical Center, Durham, NC), Brn3b, Ngn2, and Otx2 (from Dr. Lin Gan, University of Rochester, Rochester, NY), Chx10 and Mitf (from Dr. Roderick R. McInnes, Hospital for Sick Children, Toronto, Ontario, Canada), Crx and Math3 (from Valerie Wallace, Ottawa Health Research Institute, Ottawa, Ontario, Canada), Fgf15 (from Minh-Thanh T. Nguyen, National Institutes of Health, Bethesda, MD), Math5 (from Dr. Tom Glaser, University of Michigan, Ann Arbor, MI), and Pax6 and Hes1 (from Naoki Takahashi, Nara Institute of Science and Technology, Nara, Japan). At least three embryos of each genotype were analyzed for each probe.

Explant culture. Heads of E10 embryos (26-30 somites) were cut sagittally at the midline and laid flat on Millipore Corporation filters (Nitrocellulose Membrane Black Gridded, filter type $0.45 \mu \mathrm{m}$ ) floating on DMEM/F-12 (1:1) (Invitrogen) culture medium. Heparin acrylic beads (Sigma) soaked with $0.1 \%$ BSA or $250 \mu \mathrm{g} / \mathrm{ml}$ recombinant FGF2 (R \& D Systems) were inserted around the eye region as described previously (Pan et al., 2008). After $3 \mathrm{~d}$ of incubation at $37^{\circ} \mathrm{C}$ with $5 \% \mathrm{CO}_{2}$, the cultured head slices were photographed and fixed with $4 \%$ PFA before RNA in situ hybridization.

\section{Results}

Six3-Cre and $\alpha$-Cre-mediated Shp2 deletion did not disrupt retinal development

To determine the role of $\operatorname{Shp} 2$ during retinal development, we first crossed the Shp $2^{\text {flox }}$ with Six3-Cre, which we confirmed to express Cre recombinase to induce $R 26 R$ reporter activity in the 

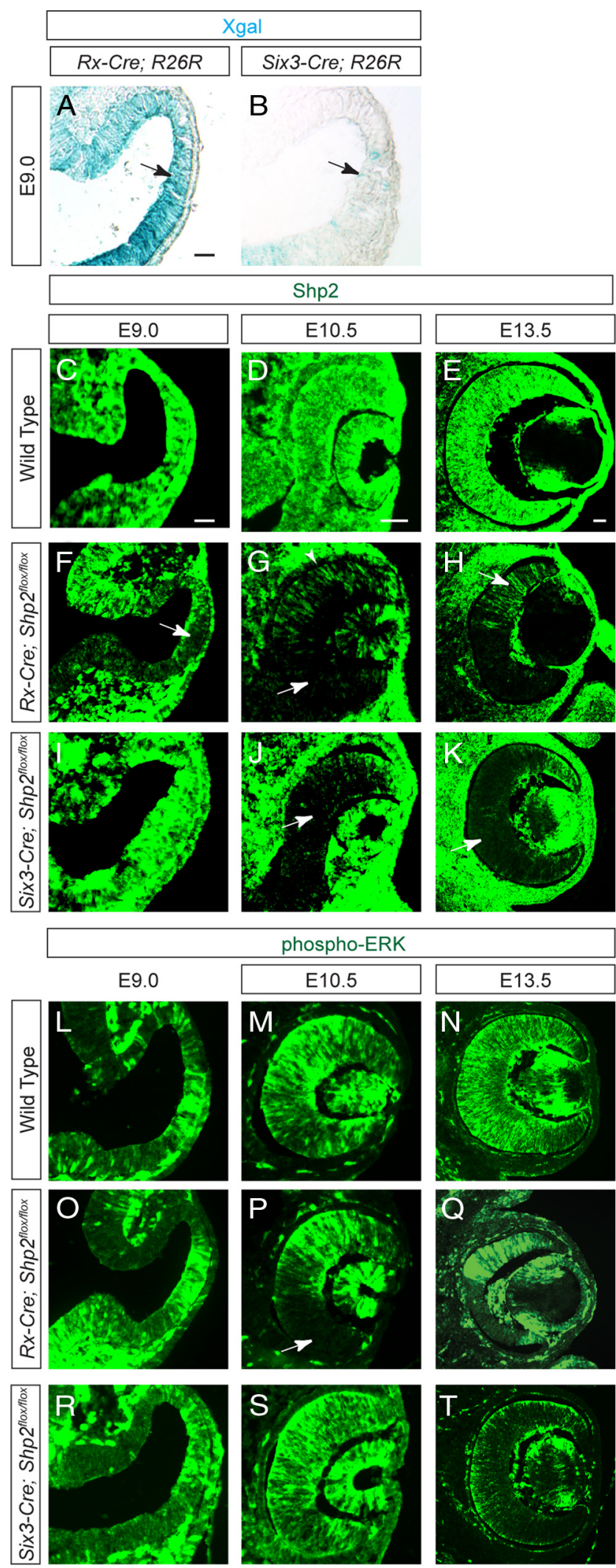

Figure 2. The time course of $R x$-Cre- and Six3-Cre- mediated Shp2 and phospho-ERK depletion. $\boldsymbol{A}, \boldsymbol{B}, R x$-Cre but not Six3-Cre activated strong $R 26 R$ reporter expression in E9.0 optic vesicle. $\mathbf{C}-\boldsymbol{K}$, Reduction of Shp2 staining was first observed in the $R x-C r e ; S h p 2^{f l o x}{ }^{\prime f l o x}$ mutant optic vesicle at $\mathrm{E9} .0$ and in the Six3-Cre;Shp2 ${ }^{\text {floxfflox }}$ mutant at E10.5. In the Rx-Cre;Shp2 $2^{\text {floxfflox }}$ mutant, notice the loss of Shp2 staining in the future RPE (arrowhead in $\boldsymbol{G}$ ) and mosaic pattern depletion of Shp2 in retina (arrow in $\boldsymbol{H}$ ). $\boldsymbol{L}-\boldsymbol{T}$, As a consequence, disruption of phospho-ERK staining was observed in the $R x-C r e ; S h p 2^{f l o x}$ flox mutant optic vesicle at E10.5 but significantly central neural retina (supplemental Fig. $\mathrm{S} 1 A, B$, available at www. jneurosci.org as supplemental material) (Furuta et al., 2000). As expected, this also led to retinal-specific ablation of Shp2 protein (Fig $1 A, D$ ). We next analyzed the wave of retinal differentiation by focusing on the expressions of Math 5 and Brn3b, two transcription factors required for retinal ganglion cell development (Erkman et al., 1996; Gan et al., 1996; Brown et al., 2001; Wang et al., 2001). Math5 expression initiates from the center of the mouse retina at E11.5, and gradually spreads toward the peripheral tip of the retina. This is immediately followed at E12.5 by a wave of Brn3b expression, which also progresses from the central retina to the peripheral retina. For both markers, we found the speed and extent of retinal ganglion cell differentiation was not changed between the wild-type and mutant retina $(n=5)$ (supplemental Fig. S1C-N, available at www.jneurosci.org as supplemental material) (Fig. $1 A-F)$. Therefore, Shp2 inactivation mediated by Six3-Cre did not affect retinal ganglion differentiation wave.

Because Six3-Cre transgene is primarily active in the central retina, it may not be able to inactivate $\operatorname{Sh} 22$ efficiently in the peripheral retina. We therefore generated another $\operatorname{Sh} 22$ conditional knock-out using the $\alpha$-Cre transgene, which has been shown previously to be active in the distal retina (Marquardt et al., 2001). Indeed, we showed that the Shp2 expression was completely abolished at the tip of the $\alpha$-Cre;Shp $2^{\text {flox/flox }}$ mutant retina (Fig. 1G). Nevertheless, the expressions of the Math5 and Brn3b were again unaffected by the $\alpha$-Cre- mediated Shp2 deletion (Fig. $1 H, I)$. Thus, retinal ganglion cell differentiation in the distal region of the retina also appeared to be insensitive to $\operatorname{Shp} 2$ ablation. In the postnatal Six3-Cre;Shp $2^{\text {flox/flox }}$ and $\alpha$-Cre;Shp $2^{\text {flox/flox }}$ mutants using the retinal neuron markers Brn3a and Islet1 (ganglion cells), calbindin and NF165 (horizontal cells), VC1.1 and syntaxin (amacrine cells), Chx10 (bipolar cells), glutamine synthetase (Müller cells), recoverin and rhodopsin (photoreceptors), we failed to observe any retinal differentiation defects (Z.C. and X.Z., unpublished observations).

\section{Rx-Cre but not Six3-Cre disrupted Shp2-ERK signaling in optic vesicle development}

The lack of retinal developmental defects in the Six3-Cre;Shp $2^{\text {flox/flox }}$ and $\alpha$-Cre;Shp $2^{\text {flox/flox }}$ mutants prompted us to consider the possibility that Shp2 signaling is only required in early optic vesicle patterning. Six $3-C r e$ and $\alpha$-Cre were reported to be first active at E9.0 and E10.5, respectively (Furuta et al., 2000; Marquardt et al., 2001). Careful expression analysis has shown previously that the murine $R x$ gene becomes highly expressed in the prospective optic vesicle at E8.5, preceding Six3 expression in the region of optic evaginations by a few hours (Furukawa et al., 1997b). We thus obtained from Dr. Milan Jamrich the $R x-C r e$ deletor (Swindell et al., 2006). Interestingly, compared with the abundant $R 26 R$ Cre reporter expression induced by the $R x-C r e$ in the optic vesicle at E9.0 (16-20 somites), hardly any ocular Xgal (5-bromo-4-chloro-3indolyl- $\beta$-D-galactopyranoside) staining was observed in the Six3Cre;R26R embryos (Fig. 2A,B, arrows). Consistent with this, although Shp2 protein was ubiquitously expressed throughout retinal development in wild-type embryos (Fig. $2 C-E$ ), in the $R x-C r e ; S h p 2^{\text {flox/flox }}$ mutant, Shp2 protein expression was reduced

delayed in Six3-Cre;Shp $2^{\text {flox/flox }}$ mutant retina until E13.5. The embryos at the same stages share the scale bars $(50 \mu \mathrm{m})$. All sections are coronal with the dorsal retina at the top. Xgal, 5-Bromo-4-chloro-3-indolyl- $\beta$-D-galactopyranoside. 
in the optic vesicle as early as E9.0 (Fig. 2 F, arrow). At E10.5 when the optic vesicle invaginated to form the optic cup, the Shp2 protein was most significantly downregulated in the ventral retina and the retinal pigmented epithelium (Fig. $2 G$, arrow and arrowheads, respectively), although mosaic patches of Shp2positive cells still existed in $R x-C r e ; S h p 2^{\text {flox/flox }}$ mutant retina at E13.5 (Fig. $2 H$, arrow). In contrast, Shp2 immunostaining only began to be reduced in the Six3-Cre;Shp $2^{\text {flox/flox }}$ mutant optic vesicle at E10.5, confirming the relatively late ablation of Shp2 protein mediated by the Six3-Cre (Fig. 2 J, arrow). Nevertheless, Shp2 protein was indeed depleted in the central region of the Six3-Cre;Shp2 $2^{\text {flox/flox }}$ mutant retina at E13.5 (Fig. 2 K, arrow). Importantly, there was also longer delay in the disruption of phospho-ERK, a downstream effector of FGF-Ras signaling, in the Six3-Cre;Shp $2^{\text {flox/flox }}$ mutant. In the Rx-Cre;Shp $2^{\text {flox/flox }}$ mutant, clear loss of phospho-ERK staining was detected particularly in ventral retina at E10.5 (Fig. $2 P$, arrow), but, in the Six3-Cre;Shp $2^{\text {flox/flox }}$ mutant, phospho-ERK expression persisted in the retina until E13.5. Therefore, $R x$-Cre activates earlier than Six3-Cre to disrupt Shp2 signaling during optic vesicle development.

\section{Shp2 is required for retinal development but not the movement of neurogenic wave in the Rx-Cre;Shp $2^{\text {flox/flox }}$ mutant}

We next investigated the retinal development in the $R x-C r e$; $S h p 2^{\text {flox/flox }}$ mutant. Compared with the wild-type embryos, the E14.5 Rx-Cre;Shp $2^{\text {flox/flox }}$ mutants exhibited mosaic depletion of Shp 2 mostly in the ventral neural retina (Fig. $3 A, A^{\prime}$, arrow). This matched that of the loss of phospho-ERK staining on adjacent sections, demonstrating the requirement of Shp 2 for ERK signaling (Fig. $3 B, B^{\prime}$, arrow). In the rest of this study, we always carefully confirmed the Shp2 and phospho-ERK deficiency on adjacent sections before proceeding to examine the rest of retina because of the mosaic nature of Shp2 depletion in the Rx-Cre; Shp $2^{\text {flox/flox }}$ mutants. By RNA in situ hybridization, we showed that the Shp2 mutant cells expressed RPE marker Mitf at the expense of retinal neuronal marker $C h \times 10$ (Fig. $3 C^{\prime}, D^{\prime}$, arrows). Moreover, there was significant downregulation of Cyclin D1 expression, which led to a severe loss of Ki67 protein, a cell cycle marker (Fig. $3 E, E^{\prime}, F, F^{\prime}$ ).

The profound cell proliferation defects in the Rx-Cre;Shp $2^{\text {flox/flox }}$ mutants preclude a comprehensive survey of all retinal cell types in adult animals; we thus focused on the embryonic retinal development. Pax6, a key eye determination gene, was expressed in the $R x-C r e ; S h p 2^{f l o x / f l o x}$ mutant throughout eye development, suggesting that $S h p 2$ ablation did not affect the specification of the eye field (Fig. $3 G, G^{\prime}$, arrow; and data not shown) (Hogan et al., 1986; Hill et al., 1991). Math3, Mash1, Ngn2, and Hes1 are basic helix-loop-helix transcription factors important for retinal differentiation (Furukawa et al., 2000; Inoue et al., 2002). By RNA in situ hybridization, we showed that the expressions of these genes were all disrupted in E14.5 Rx-Cre;Shp $2^{\text {flox/flox }}$ mutants (Fig. $3 H^{\prime}-L^{\prime}$, arrows). We next analyzed the retinal neurons that were born at E14.5 (retinal ganglion, amacrine, horizontal cells, and photoreceptors) to further investigate the retinal differentiation defects. Ptfla, a transcription factor specifying retinal amacrine and horizontal cells, was significantly downregulated in the $R x-$ Cre;Shp $2^{\text {flox/flox }}$ mutant retina (Fig. $3 L, L^{\prime}$, arrow) (Fujitani et al., 2006; Nakhai et al., 2007). The expression of Otx2 and Crx, two homeodomain transcription activators that control photoreceptor cell development, were abolished in the Shp2-deficient retina (Fig. $3 M^{\prime}, N^{\prime}$, arrows) (Chen et al., 1997; Freund et al., 1997;
Furukawa et al., 1997a). Consistent with this, the early cone cell marker TR $\beta 2$ was also lost (Fig. 3O, $\mathrm{O}^{\prime}$, arrow) (Roberts et al., 2006; Ng et al., 2009). Finally, the Rx-Cre;Shp $2^{\text {flox/flox }}$ mutant retina exhibited significant loss of Math 5 and Brn3b expression, which are essential for retinal ganglion cell differentiation (Fig. $3 P^{\prime}, Q^{\prime}$, arrows). As a result, the neural filament marker NF165 was abolished (Fig. $3 R, R^{\prime}$, arrow). Together, these results demonstrated that the mosaic depletion of Shp2 in the Rx-Cre; $S h p 2^{f l o x / f l o x}$ mutant disrupted retinal differentiation.

The mosaic pattern of $\operatorname{Sh} p 2$ ablation in the $R x-C r e ; S h p 2^{\text {flox/flox }}$ embryos also allowed us to test the sequential-induction model for mammalian retinal development, which predicts that the early differentiated proximal retina is required for the development of the distal retina. We reasoned that, if FGF signaling participates in such a mode of tissue induction, disruption of FGF signaling by $\operatorname{Sh} p 2$ ablation should prevent the progression of the retinal differentiation wave. Erm is an ETS domain transcription factor inducible by FGF signaling during embryonic development (Munchberg and Steinbeisser, 1999; Raible and Brand, 2001; Roehl and Nüsslein-Volhard, 2001). In the Rx-Cre;Shp $2^{\text {flox/flox }}$ mutants in which Shp2 was only depleted in a small patch of the retina (Fig. $4 A, D$, brackets), the Shp2 ablation area fit exactly the region deficient in Erm expression on an adjacent section, suggesting a loss of FGF signaling in this area (Fig. $4 B$, E, brackets). Within the Shp2 mutant domain in the Rx-Cre;Shp $2^{\text {flox/flox }}$ retina, the expression of Math5, the retinal neurogenic wave marker, was lost in the cells closer to the distal retina (Fig. 4C,F, black arrowheads) but preserved in the cells closer to the proximal retina that had differentiated earlier, demonstrating that $\operatorname{Shp} 2$ is not required for maintenance of retinal differentiation (Fig. 4C,F, black arrows). Furthermore, the wild-type cells distal to the $\operatorname{Shp} 2 \mathrm{mu}-$ tant cells also expressed Math5, suggesting that wild-type retinal cells can differentiate cell autonomously adjacent to $\operatorname{Sh} p 2$ mutant cells (Fig. 4C,F, red arrow). To determine whether isolated wildtype clones completely surrounded by Shp2 mutant cells could still differentiate independently, we performed whole-mount in situ hybridization and found islands of Fgf15-expressing retinal progenitor cells close to the periphery at E15.5 (Fig. 4G, arrow). By triple-fluorescent staining on serial sections, we then mapped the three-dimensional structure of the Shp2 mutant retina. Although the immunohistochemistry condition for the Shp2 antibody is not optimum for other markers, because our above analysis has shown that retinal Mitf expression was induced only in the Shp2 mutant cells, we were able to identify the Shp2 mutant domain by its ectopic expression of Mitf. The wild-type retinal cells were identified by Fgf15, which marks the retinal progenitor cells in the ventricular zone, and Islet1, which predominantly labels newly differentiated retinal ganglion cell at this stage (Rachel et al., 2002; Elshatory et al., 2007). At the passage of the neurogenic wave, Islet1-positive cells emerged from the Fgf15expressing neuroblasts in the proximal retina (Fig. $4 H-L$, arrows and arrowheads), but no Islet1-positive cells were found in the Mitf-expressing zone (Fig. $4 H-L$, white brackets), consistent with our above results that $S h p 2$ is required for retinal differentiation. However, reconstruction of the serial images showed that a cluster of Fgf15-expressing wild-type cells in the distal retinal, although completely enclosed in an Mitf-expressing mutant domain, were still able to commence Islet1 expression (Fig. $4 H-L$, yellow brackets). Therefore, these distal retinal cells can apparently initiate neuronal differentiation program without direct physical contact with the proximal wild-type retina, demonstrating the Shp2 mutation clones were unable to block the movement of the retinal neurogenic wave. 

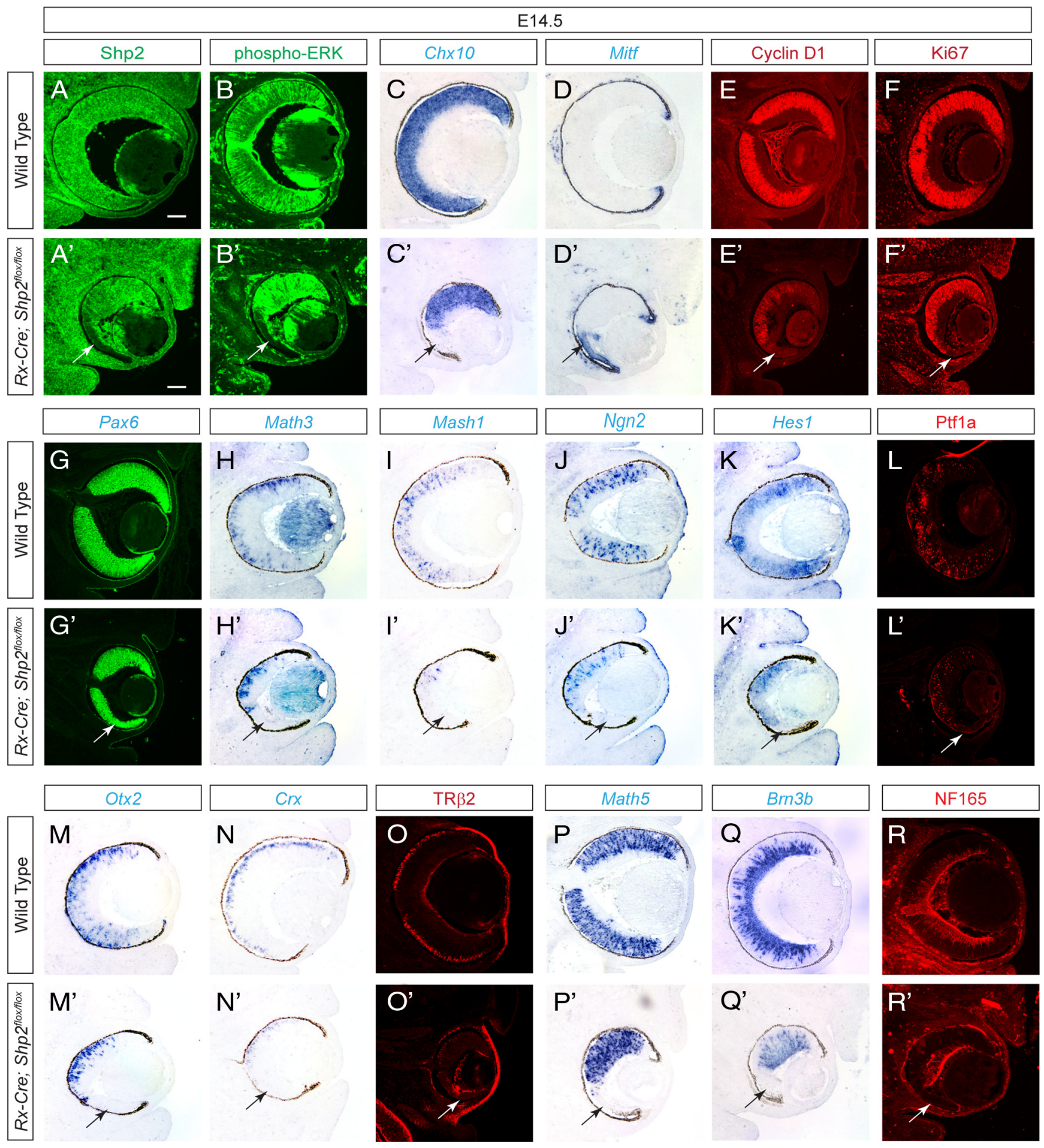

Figure 3. Rx-Cre-mediated Shp2 ablation disrupted retinal development. $\boldsymbol{A}-\boldsymbol{F}, \boldsymbol{A}^{\prime}-\boldsymbol{F}^{\prime}$, At E14.5, mosaic depletion of Shp2 in the $R x-\left(r e ; S h p 2^{\text {floxfflox }}\right.$ mutant retinae not only disrupted phospho-ERK staining but also resulted in the loss of Cyclin D1, Ki67, and Chx10 expression. In contrast, Mitf expression was upregulated (arrows). $\mathbf{G}-\boldsymbol{K}, \boldsymbol{G}^{\prime}-\boldsymbol{K}^{\prime}$, The eye field specification gene Pax6 is unchanged, but the retinal differentiation genes Math3, Math1, Ngn2, and Hes 1 are all lost in the Rx-Cre; Shp $2^{\text {floxfflox }}$ mutant retinae (arrows). $\boldsymbol{L}-\boldsymbol{R}, \boldsymbol{L}^{\prime}-\boldsymbol{R}^{\prime}, \mathbf{L}$ Loss of Ptf1a indicated the disruption of retinal amacrine and horizontal cell differentiation. Loss of Otx2, Crx and TR $\beta 2$ indicated photoreceptor cell defects. Loss of Math5, Brn3b, and NF165 indicated retinal ganglion cells defects. Scale bars, $100 \mu \mathrm{m}$.

\section{Shp2 controls FGF-Kras signaling during} retinal development

To investigate the mechanism of Shp2 function in retinal development, we next examined the $R x-C r e ; S h p 2^{f l o x / f l o x}$ mutant retina at E12.5 before cell proliferation defects had significantly distorted retinal morphogenesis. After confirming the loss of Shp2 and phospho-ERK expression, we found that the retinal progenitor cell markers Sox2 and Chx10 were also abolished (Fig. 5A$D, G-J$, arrows) (Burmeister et al., 1996; Taranova et al., 2006). We also noticed that RPE-like pigmented cells were frequently present at the tip of the $R x-C r e ; S h p 2^{\text {flox/flox }}$ retina (Fig. $5 L$, arrowhead), and the RPE determination gene Mitf was ectopically ex- 

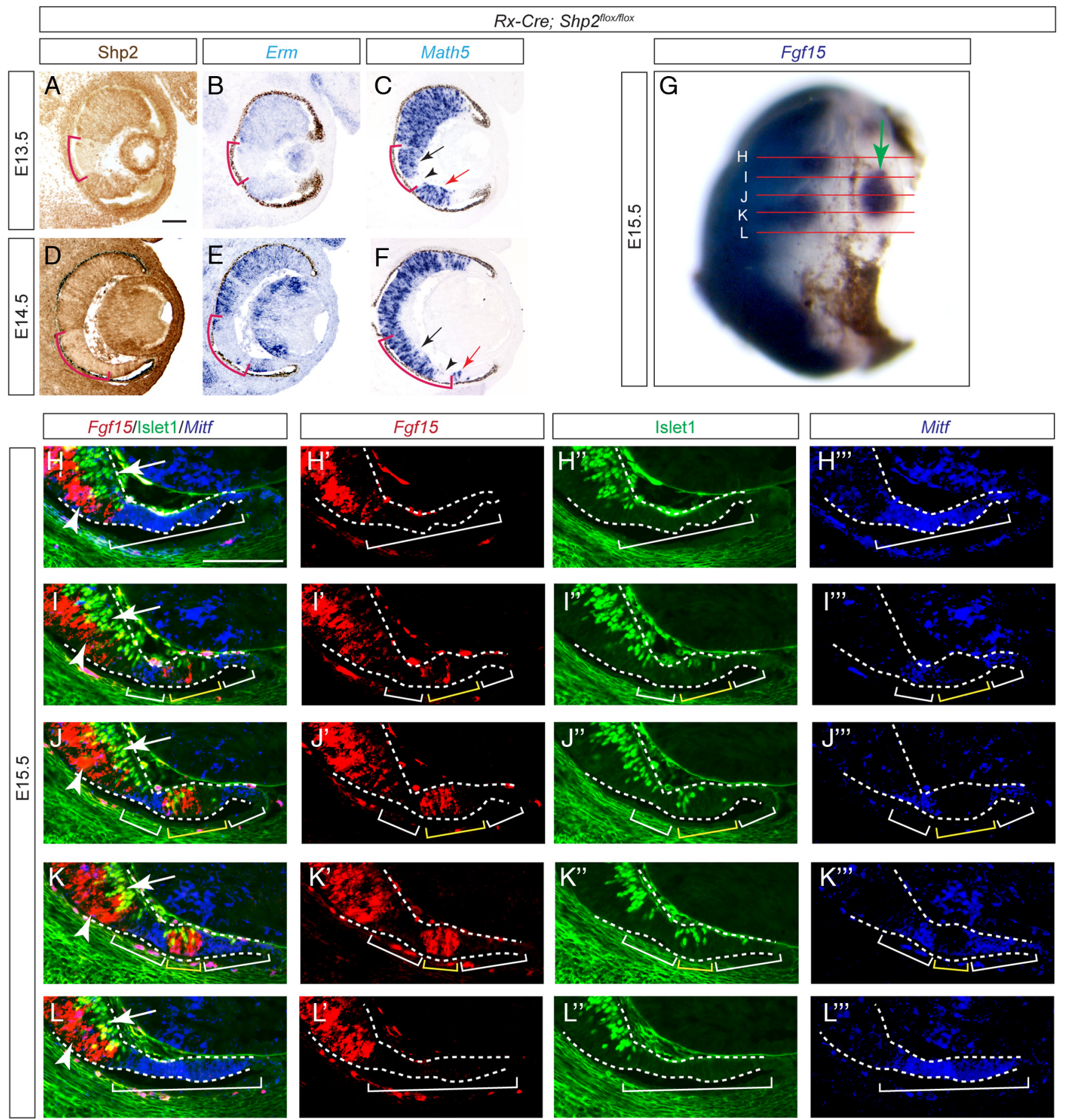

Figure 4. Shp2 ablation did not affect the neurogenic wave progression. $\boldsymbol{A}-\boldsymbol{F}$, 0 adjacent sections, although the Shp2 depletion pattern region exactly matched the Erm-deficient zone (red brackets), only the distal portion of the Shp2-negative zone lost Math5 expression (black arrow and arrowheads). Moreover, the wild-type cells distal to the Shp2-deficient zone still expressed Math5 (red arrows). G, Whole-mount in situ hybridization identified an island of Fgf15-expressing retinal progenitor cells isolated from proximal retina (arrow). The red lines indicated the serial sections used in $\boldsymbol{H}-\boldsymbol{L}$ to fully map the Fgf15-positive domains. $\boldsymbol{H}-\boldsymbol{L}$, By combining fluorescent RNA in situ hybridization (Fgf15 and Mitf) and immunofluorescence (Islet1), we identified the Fgf15/slet1positive cell clusters (arrows and arrowheads within the yellow brackets) enclosed in the Mitf-positive domain (white brackets), demonstrating that neural differentiation can occur in the isolated wild-type cells in distal retina without direct contact with the proximal retina. Scale bars, $100 \mu \mathrm{m}$.

pressed in distal retina, demonstrating that the Shp2 mutant cells had shifted from a neural retinal fate to RPE fate (Fig. $5 E, K$, arrow). Finally, we observed that Fgf15 expression was abolished in the Mitf-expressing domain, indicating that Shp2 signaling controlled FGF ligand expression (Fig. 5F,L, arrow).

We next examined whether Shp2 could also act downstream to FGF signaling to induce the optic vesicle into the neural retina.
This was tested by in vitro explant culture experiments, given that Shp2 is also deleted in presumptive RPE region of $R x-C r e$; Shp $2^{\text {flox/flox }}$ embryos at E10.5 (Fig. $2 G$, arrowhead). As a control, we first implanted BSA-soaked beads adjacent to the eye rudiments collected from E10.5 wild-type embryos. As expected, BSA beads did not perturb the development of the optic vesicle into Chx10-expressing neural retina and Mitf-expressing RPE (Fig. 


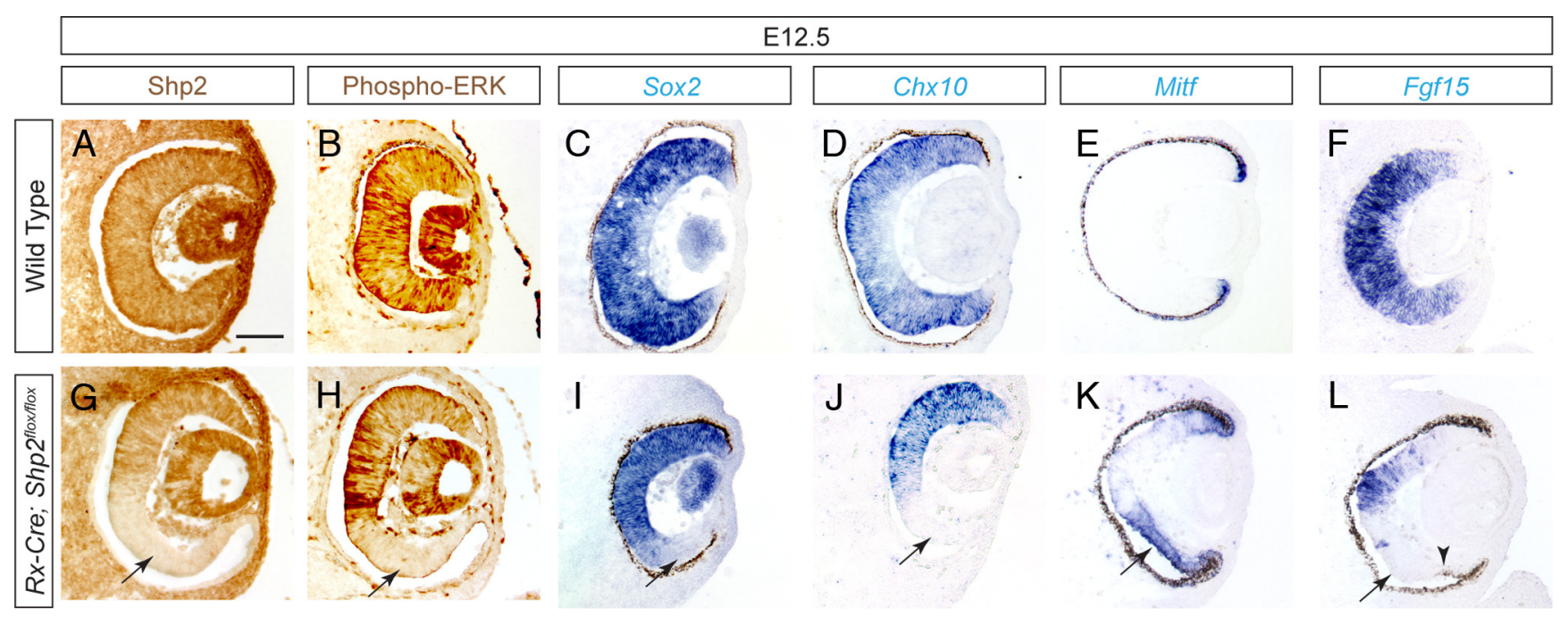

Figure 5. Shp2 signaling promotes the neural retinal fate against retinal pigmented epithelium fate. AtE12.5, the Shp2 null cells in Rx-Cre;Shp2 flox/flox mutants maintained the expression of the eye field specification gene Pax6 but lost the retinal progenitor markers Sox2 and $C h \times 10(\boldsymbol{A}-\boldsymbol{D}, \mathbf{G}-\boldsymbol{J}$, arrows). There was a corresponding invasion of $M i t f$ expression into the presumptive neural retinal domain and loss of Fgf15 expression $(\boldsymbol{F}, \boldsymbol{L}$, arrow). Notice the presence of pigmented RPE cells in the tip of the mutant retina ( $\boldsymbol{L}$, arrowhead). Scale bar, $100 \mu \boldsymbol{m}$.

$6 A, D, G$, arrows). FGF2-soaked beads, however, induced obvious loss of pigmentation in the adjacent eye tissue (Fig. $6 \mathrm{~B}$, arrow) (13 of 16 wild-type explants). By RNA in situ hybridization, we further confirmed that exogenous FGF2 induced the duplication of Chx10-positive neural retina and corresponding loss of Mitfpositive RPE in wild-type eye rudiments (Fig. $6 E, H$, arrows). Finally, FGF2 beads failed to transform RPE into neural retina in six of nine $R x-C r e ; S h p 2^{f l o x f f l o x}$ embryos (Fig. $5 C$, arrow) ( $p=0.0308$, Fisher's exact test). In these mutant embryos, Mitf expression was not only preserved in RPE tissue adjacent to the FGF2 beads but also extended into the presumptive retinal region (Fig. 6I, arrow and arrowhead, respectively). Therefore, FGF signaling depends on Shp2 in directing neural retinal fate.

To define the downstream target of Shp2 in retinal-specific FGF signaling, we next asked whether activated Ras could ameliorate the Rx-Cre;Shp $2^{\text {flox/flox }}$ mutant phenotype. To conditionally express an activated form of Ras at a physiologically relevant level, we used the LSL-Kras ${ }^{G 12 D}$ mouse, which carries a missense $G$ to $D$ mutation at codon 12 in the endogenous Kras gene, resulting in constitutive Ras signaling by disruption of the GTPase activity of Kras (Tuveson et al., 2004). Normally silenced by an insertion of a transcription stop cassette flanked by two LoxP sites, the LSL-Kras ${ }^{G 12 D}$ allele was able to be activated by the same $R x-C r e$ transgene while $\operatorname{Sh} p 2$ was

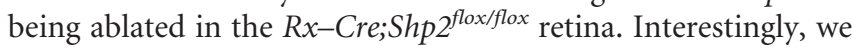
did not observe any overt ocular phenotype in the Rx-Cre; $L S L-$ $\mathrm{Kras}^{G 12 D}$ animals, suggesting that activated Kras expressed at a $200 \mu \mathrm{m}$.
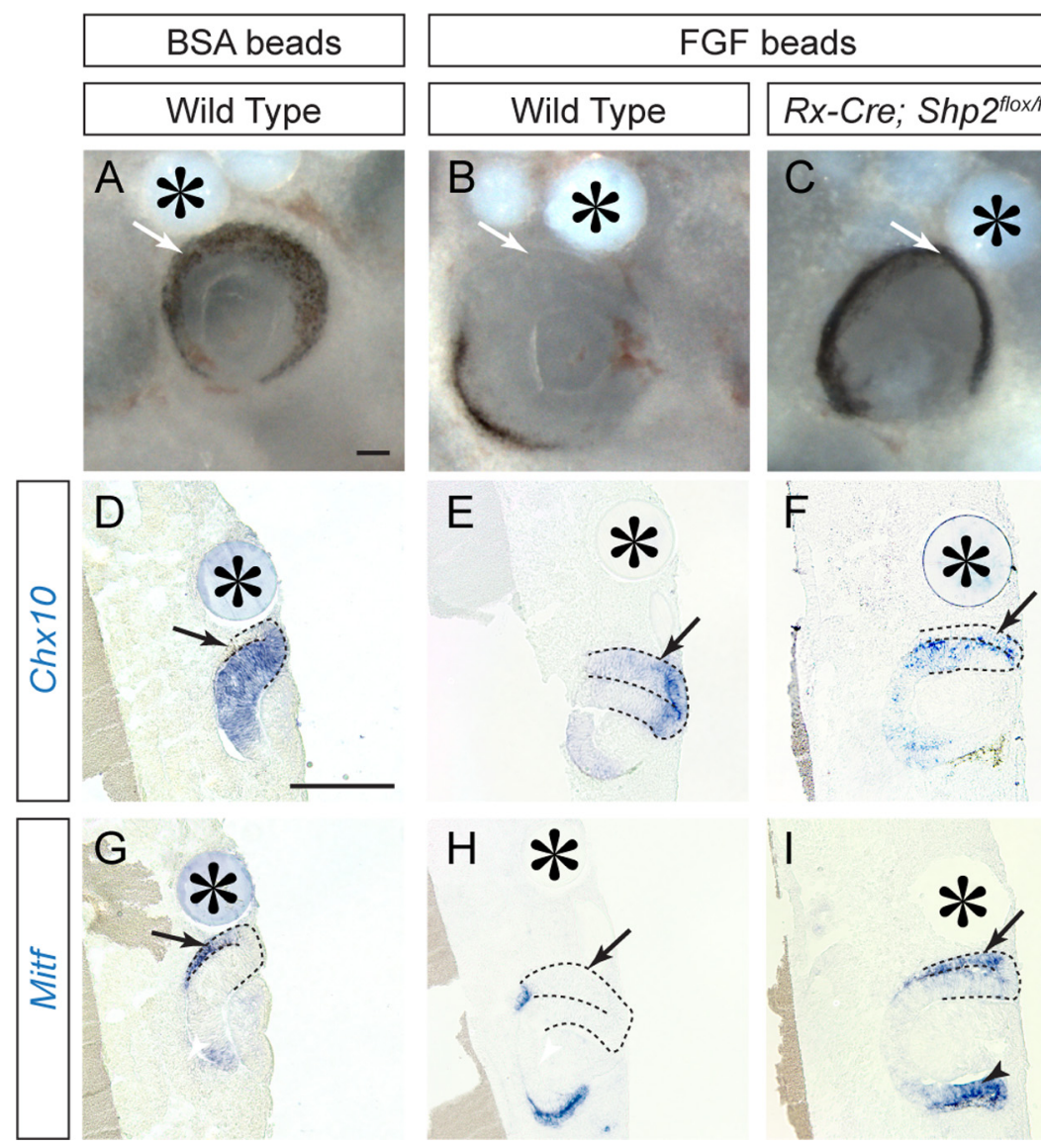

Figure 6. FGF signaling depended on Shp2 to induce neural retina in optic vesicle. $A, D, G$, Wild-type retinal culture developed with proper demarcation of Chx10 and Mitf expressions in the presence of BSA beads (arrows). $\boldsymbol{B}, \boldsymbol{E}, \boldsymbol{H}$, In wild-type cultures, FGF2 beads transformed the Mitf-expressing RPE into Chx10-expressing the neural retina (arrows). C, F, I, In Rx-Cre;Shp2 $2^{f l o x}$ fflox mutants, FGF2 beads were unable to induce RPE into the neural retina (arrowheads). Asterisks denote implanted beads. Scale bars,

moderate level from its endogenous locus did not perturb regular eye development. The retinae in the $R x-C r e ; S h p 2^{f l o x}$ flox embryos, however, showed mosaic depletion of Shp2 and an identical pattern of phospho-ERK downregulation (Fig. $7 F, G$, arrows), which 

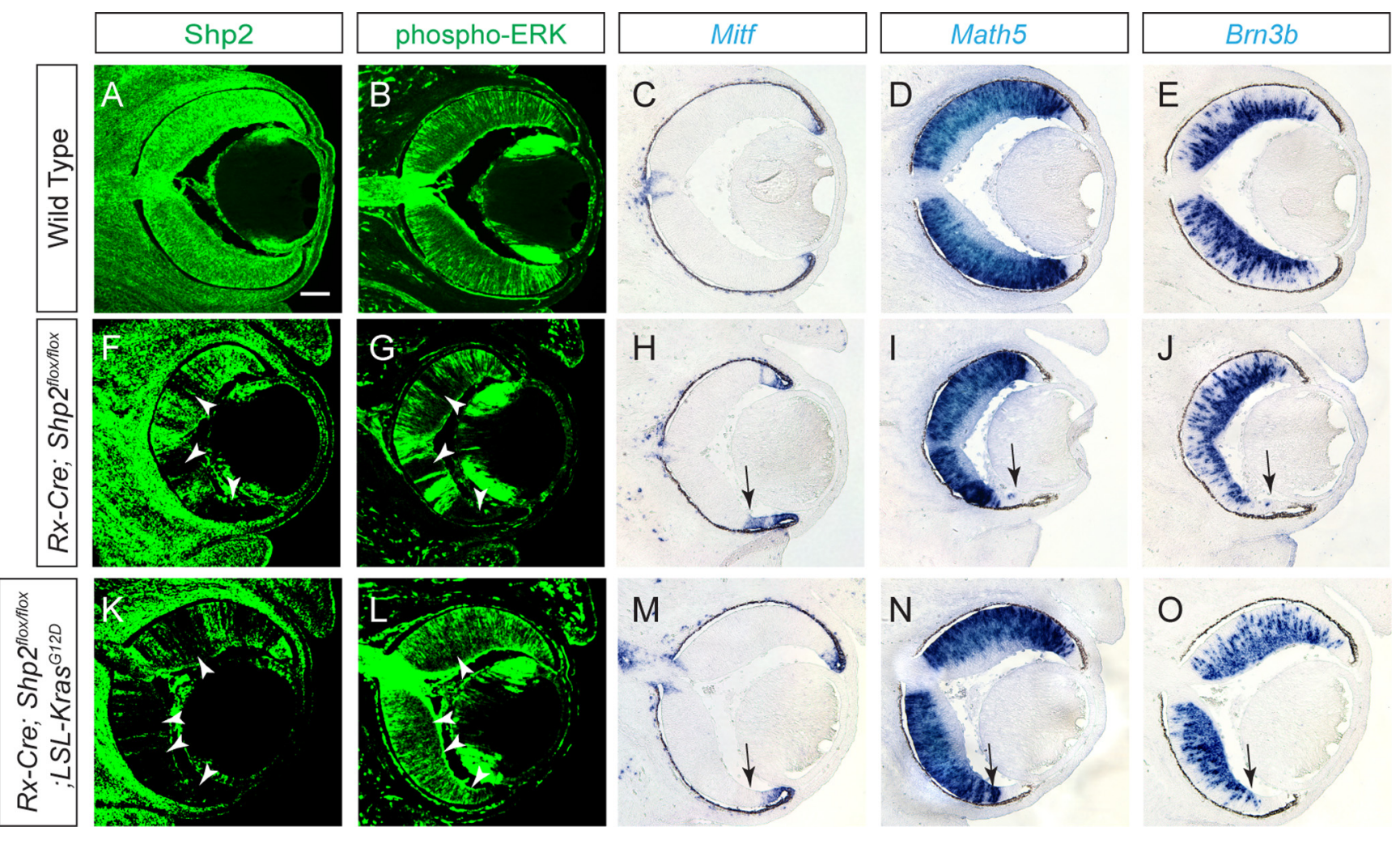

Figure 7. Activated Ras signaling rescued Shp2 mutant retinal development. $A-E$, In the E14.5 wild-type embryos, Shp2, phospho-ERK, Math5, and Brn3b were expressed throughout the retina, whereas Mitf expression was restricted to the tip of the retina. $\boldsymbol{F}-\boldsymbol{J}$, Mosaic depletion of Shp2 in the Rx-Cre; Shp $2^{\text {floxfflox }}$ mutants led to a loss of phospho-ERK, Math5, and Brn3b expressions, whereas

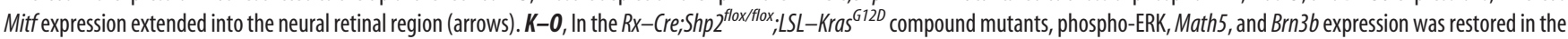
Shp2-negative cells, whereas Mitf was properly expressed in the tip of the retina (arrowheads). Scale bar, $100 \mu \mathrm{m}$.

led to invasion of Mitf and corresponding loss of Math5 and Brn3b expression in the distal retinae (Fig. $7 \mathrm{H}-\mathrm{J}$, arrows). Consistent with the activation of Ras signaling by the $\mathrm{Kras}^{G 12 D}$ allele, the $R x-C r e ; S h p 2^{f l o x} / f l o x ;$

$L S L-$ ras $^{G 12 D}$ compound mutants exhibited random patches of Shp2 depletion but normal level of phospho-ERK throughout the retinae (Fig. $7 \mathrm{~K}, L$ ). More importantly, Mitf expression was confined to the retinal tip, whereas the expression of Math5 and $B r n 3 b$ extended uninterruptedly into the distal retina (Fig. $7 M-O$, arrows). The genetic rescue of the Shp2 mutation by the $\mathrm{Kras}^{G 12 D}$ allele thus demonstrated that the Shp2 mutant phenotype could be fully explained by the loss of Ras signaling during retinal development.

\section{Discussion}

In this study, we have generated three temporally distinct models of Shp2 ablation during retinal development. Interestingly, unlike the severe retinal defects in the $R x-C r e ; S h p 2^{f l o x / f l o x}$ mutants, the Six3-Cre and $\alpha$-Cre-mediated knock-outs of Shp2 had no discernable effect on embryonic retinal development. For example, although the expressions of the retinal progenitor marker such as Sox2 and Chx10 or retinal differentiation genes such as $\mathrm{Brn} 3 \mathrm{~b}$ and $\mathrm{Cr} x$ were lost in the $\mathrm{Rx}-\mathrm{Cre} ; \mathrm{Sh} \mathrm{p}^{f l o x / f l o x}$ mutant retina, none of these retinal-specific factors were disrupted in the Six3Cre;Shp $2^{f l o x / f l o x}$ or the $\alpha$-Cre;Shp $2^{f l o x}$ flox mutant retina. As a result, only the Rx-Cre;Shp $2^{\text {flox } f f l o x}$ mutant embryos exhibited the loss of the early ganglion marker NF165 and cone cell marker $\operatorname{TR} \beta 2$. These phenotypic differences are unlikely attributable to the lack of Cre expression, because both Six3-Cre and the $\alpha$-Cre are efficient Cre drivers widely used in studying retinal develop- ment, and we also showed that Shp2 protein were indeed depleted in the Six 3-Cre;Shp $2^{\text {flox/flox }}$ and the $\alpha$-Cre;Shp $2^{\text {flox/flox }}$ mutant retina at E14.5. Conversely, our Cre reporter assay and immunohistochemistry clearly showed that $R x-C r e$ acted earlier than Six3-Cre, depleting Shp2 at E9.0 and E10.5, respectively, and previous study has also shown that $\alpha$-Cre becomes first active at E10.5. These results suggest that Shp2 signaling is only required in a narrow time window during early retinal development. Indeed, we have further showed that the Rx-Cre;Shp $2^{\text {flox flox }}$ mutant retina ectopically expressed RPE marker Mitf but suppressed the neural progenitor marker Chx10 and Sox2, suggesting a general fate change from neural retinal fate into RPE fate. This disruption of early ocular tissue specification thus provides the simplest explanation for the pleiotropic loss of retinal neurogenesis in the $R x-C r e ; S h p 2^{f l o x / f l o x}$ mutants. Shp2 signaling in the brain is also known to act as a critical switch in biasing cortical precursor cells and neural stem cells toward a neuronal fate rather than a glial fate (Gauthier et al., 2007; Ke et al., 2007). Therefore, Shp2mediated growth factor signaling may play a general role in promoting neural cell fate during nervous system development.

If the retinal defects in the $R x-C r e ; S h p 2^{f l o x / f l o x}$ mutants can be readily explained by the general failure of retinal fate determination, does Shp2 signaling still play a role in retinal differentiation? In species ranging from Drosophila to mammals, retinal differentiation spreads in a fan-like manner from the root of the optic stalk to the edge of the retina. The most elegant hypothesis to explain this strikingly conserved pattern of the retinal differentiation wave is the sequential-induction model, in which earlier differentiated retinal neurons secrete diffusible factors to induce neighboring retinal progenitor cells to differentiate (Ma et al., 
1993; Greenwood and Struhl, 1999; Neumann and NuessleinVolhard, 2000). In addition to Sonic hedgehog, FGF has emerged as a potential signal for both the initiation and the progression of the neurogenic wave in vertebrates (Martinez-Morales et al., 2005; Vinothkumar et al., 2008). However, previous results have also shown that isolation of retinal fragments from the rest of eye did not abolish their neuronal differentiation (McCabe et al., 1999; Kay et al., 2005). In our current study, we showed that the retinal differentiation wave in the $R x-C r e ; S h p 2^{\text {flox/flox }}$ mutants could move across the Shp2 mutant clones to reach more distal retinal cells. Furthermore, retinal differentiation proceeded normally in the Six3-Cre;Shp $2^{\text {flox/flox }}$ and $\alpha$-Cre;Shp $2^{\text {flox/flox }}$ mutants in which the Shp2 ablation occurred during retinal differentiation. These results suggest that Shp2 is not required for progression and maintenance of neurogenic wave.

Our results thus support that Shp2 signaling is required for establishing the neuronal versus RPE fate in mammalian retinal development, consistent with its role in mediating FGF signaling. Indeed, Shp 2 mutation prevented the transformation of RPE into neuronal tissue by ectopic FGF in organ cultures, whereas in vivo, activated Kras can fully rescue the ERK phosphorylation and retinal defects in the $R x-C r e ; S h p 2^{\text {flox/flox }}$ mutants. These results support the FGF-Shp2-Ras-ERK signaling cascade in retinal development. Nevertheless, inhibition of FGF signaling in Xenopus embryos by dominant-negative Fgfrl expression did not disrupt the demarcation of the neural retina versus RPE or the production of retinal ganglion cells; instead, it reduced photoreceptor cell numbers (McFarlane et al., 1998). Conversely, in Xenopus-expressing dominant-negative Fgfr4, the loss of photoreceptor cells and defects in retinal lamination were observed, whereas retinal ganglion cell development was unaffected (Zhang et al., 2003). The phenotypic discrepancies between these and our studies could be attributable to the species and/or the technical difference, but it is also possible that Shp2 may mediate other receptor tyrosine kinase signaling, whereas FGF signaling may function through other Shp2-independent downstream pathways. Additional studies are required to determine the exact molecular interaction connection between FGF and Shp2 signaling and the full spectrum of FGF signaling in retinal development.

\section{References}

Brown NL, Patel S, Brzezinski J, Glaser T (2001) Math5 is required for retinal ganglion cell and optic nerve formation. Development 128:24972508 .

Burmeister M, Novak J, Liang MY, Basu S, Ploder L, Hawes NL, Vidgen D, Hoover F, Goldman D, Kalnins VI, Roderick TH, Taylor BA, Hankin MH, McInnes RR (1996) Ocular retardation mouse caused by Chx10 homeobox null allele: impaired retinal progenitor proliferation and bipolar cell differentiation. Nat Genet 12:376-384.

Chen S, Wang QL, Nie Z, Sun H, Lennon G, Copeland NG, Gilbert DJ, Jenkins NA, Zack DJ (1997) Crx, a novel Otx-like paired-homeodomain protein, binds to and transactivates photoreceptor cell-specific genes. Neuron 19:1017-1030.

Dono R, Texido G, Dussel R, Ehmke H, Zeller R (1998) Impaired cerebral cortex development and blood pressure regulation in FGF-2-deficient mice. ЕMBO J 17:4213-4225.

Elshatory Y, Deng M, Xie X, Gan L (2007) Expression of the LIMhomeodomain protein Isl1 in the developing and mature mouse retina. J Comp Neurol 503:182-197.

Erkman L, McEvilly RJ, Luo L, Ryan AK, Hooshmand F, O'Connell SM, Keithley EM, Rapaport DH, Ryan AF, Rosenfeld MG (1996) Role of transcription factors Brn-3.1 and Brn-3.2 in auditory and visual system development. Nature 381:603-606.

Feng GS (1999) Shp-2 tyrosine phosphatase: signaling one cell or many. Exp Cell Res 253:47-54.

Freund CL, Gregory-Evans CY, Furukawa T, Papaioannou M, Looser J,
Ploder L, Bellingham J, Ng D, Herbrick JA, Duncan A, Scherer SW, Tsui LC, Loutradis-Anagnostou A, Jacobson SG, Cepko CL, Bhattacharya SS, McInnes RR (1997) Cone-rod dystrophy due to mutations in a novel photoreceptor-specific homeobox gene (CRX) essential for maintenance of the photoreceptor. Cell 91:543-553.

Fujitani Y, Fujitani S, Luo H, Qiu F, Burlison J, Long Q, Kawaguchi Y, Edlund H, MacDonald RJ, Furukawa T, Fujikado T, Magnuson MA, Xiang M, Wright CV (2006) Ptfla determines horizontal and amacrine cell fates during mouse retinal development. Development 133:4439-4450.

Furukawa T, Morrow EM, Cepko CL (1997a) Crx, a novel otx-like homeobox gene, shows photoreceptor-specific expression and regulates photoreceptor differentiation. Cell 91:531-541.

Furukawa T, Kozak CA, Cepko CL (1997b) rax, a novel paired-type homeobox gene, shows expression in the anterior neural fold and developing retina. Proc Natl Acad Sci U S A 94:3088-3093.

Furukawa T, Mukherjee S, Bao ZZ, Morrow EM, Cepko CL (2000) rax, Hes1, and notch1 promote the formation of Muller glia by postnatal retinal progenitor cells. Neuron 26:383-394.

Furuta Y, Lagutin O, Hogan BL, Oliver GC (2000) Retina- and ventral forebrain-specific Cre recombinase activity in transgenic mice. Genesis 26:130-132.

Galy A, Néron B, Planque N, Saule S, Eychène A (2002) Activated MAPK/ ERK kinase (MEK-1) induces transdifferentiation of pigmented epithelium into neural retina. Dev Biol 248:251-264.

Gan L, Xiang M, Zhou L, Wagner DS, Klein WH, Nathans J (1996) POU domain factor Brn-3b is required for the development of a large set of retinal ganglion cells. Proc Natl Acad Sci U S A 93:3920-3925.

Gauthier AS, Furstoss O, Araki T, Chan R, Neel BG, Kaplan DR, Miller FD (2007) Control of CNS cell-fate decisions by SHP-2 and its dysregulation in Noonan syndrome. Neuron 54:245-262.

Greenwood S, Struhl G (1999) Progression of the morphogenetic furrow in the Drosophila eye: the roles of Hedgehog, Decapentaplegic and the Raf pathway. Development 126:5795-5808.

Guillemot F, Cepko CL (1992) Retinal fate and ganglion cell differentiation are potentiated by acidic FGF in an in vitro assay of early retinal development. Development 114:743-754.

Hill RE, Favor J, Hogan BL, Ton CC, Saunders GF, Hanson IM, Prosser J, Jordan T, Hastie ND, van Heyningen V (1991) Mouse small eye results from mutations in a paired-like homeobox-containing gene. Nature 354:522-525.

Hogan BL, Horsburgh G, Cohen J, Hetherington CM, Fisher G, Lyon MF (1986) Small eyes (Sey): a homozygous lethal mutation on chromosome 2 which affects the differentiation of both lens and nasal placodes in the mouse. J Embryol Exp Morphol 97:95-110.

Hori K, Cholewa-Waclaw J, Nakada Y, Glasgow SM, Masui T, Henke RM, Wildner H, Martarelli B, Beres TM, Epstein JA, Magnuson MA, Macdonald RJ, Birchmeier C, Johnson JE (2008) A nonclassical bHLH Rbpj transcription factor complex is required for specification of GABAergic neurons independent of Notch signaling. Genes Dev 22:166-178.

Horsford DJ, Nguyen MT, Sellar GC, Kothary R, Arnheiter H, McInnes RR (2005) Chx10 repression of Mitf is required for the maintenance of mammalian neuroretinal identity. Development 132:177-187.

Hyer J, Mima T, Mikawa T (1998) FGF1 patterns the optic vesicle by directing the placement of the neural retina domain. Development 125:869-877.

Inoue T, Hojo M, Bessho Y, Tano Y, Lee JE, Kageyama R (2002) Math3 and NeuroD regulate amacrine cell fate specification in the retina. Development 129:831-842.

Kay JN, Link BA, Baier H (2005) Staggered cell-intrinsic timing of ath5 expression underlies the wave of ganglion cell neurogenesis in the zebrafish retina. Development 132:2573-2585.

Ke Y, Zhang EE, Hagihara K, Wu D, Pang Y, Klein R, Curran T, Ranscht B, Feng GS (2007) Deletion of Shp2 in the brain leads to defective proliferation and differentiation in neural stem cells and early postnatal lethality. Mol Cell Biol 27:6706-6717.

Ma C, Zhou Y, Beachy PA, Moses K (1993) The segment polarity gene hedgehog is required for progression of the morphogenetic furrow in the developing Drosophila eye. Cell 75:927-938.

Marquardt T, Ashery-Padan R, Andrejewski N, Scardigli R, Guillemot F, Gruss P (2001) Pax6 is required for the multipotent state of retinal progenitor cells. Cell 105:43-55.

Martinez-Morales JR, Del Bene F, Nica G, Hammerschmidt M, Bovolenta P, 
Wittbrodt J (2005) Differentiation of the vertebrate retina is coordinated by an FGF signaling center. Dev Cell 8:565-574.

McCabe KL, Gunther EC, Reh TA (1999) The development of the pattern of retinal ganglion cells in the chick retina: mechanisms that control differentiation. Development 126:5713-5724.

McFarlane S, Zuber ME, Holt CE (1998) A role for the fibroblast growth factor receptor in cell fate decisions in the developing vertebrate retina. Development 125:3967-3975.

Miller DL, Ortega S, Bashayan O, Basch R, Basilico C (2000) Compensation by fibroblast growth factor 1 (FGF1) does not account for the mild phenotypic defects observed in FGF2 null mice. Mol Cell Biol 20:2260-2268.

Münchberg SR, Steinbeisser H (1999) The Xenopus Ets transcription factor XER81 is a target of the FGF signaling pathway. Mech Dev 80:53-65.

Nakhai H, Sel S, Favor J, Mendoza-Torres L, Paulsen F, Duncker GI, Schmid RM (2007) Ptfla is essential for the differentiation of GABAergic and glycinergic amacrine cells and horizontal cells in the mouse retina. Development 134:1151-1160.

Neumann CJ, Nuesslein-Volhard C (2000) Patterning of the zebrafish retina by a wave of sonic hedgehog activity. Science 289:2137-2139.

Ng L, Ma M, Curran T, Forrest D (2009) Developmental expression of thyroid hormone receptor beta2 protein in cone photoreceptors in the mouse. Neuroreport 20:627-631.

Nguyen M, Arnheiter H (2000) Signaling and transcriptional regulation in early mammalian eye development: a link between FGF and MITF. Development 127:3581-3591.

Ortega S, Ittmann M, Tsang SH, Ehrlich M, Basilico C (1998) Neuronal defects and delayed wound healing in mice lacking fibroblast growth factor 2. Proc Natl Acad Sci U S A 95:5672-5677.

Pan Y, Woodbury A, Esko JD, Grobe K, Zhang X (2006) Heparan sulfate biosynthetic gene Ndst1 is required for FGF signaling in early lens development. Development 133:4933-4944.

Pan Y, Carbe C, Powers A, Zhang EE, Esko JD, Grobe K, Feng GS, Zhang X (2008) Bud specific N-sulfation of heparan sulfate regulates Shp2dependent FGF signaling during lacrimal gland induction. Development 135:301-310.

Park CM, Hollenberg MJ (1989) Basic fibroblast growth factor induces retinal regeneration in vivo. Dev Biol 134:201-205.

Pittack C, Grunwald GB, Reh TA (1997) Fibroblast growth factors are necessary for neural retina but not pigmented epithelium differentiation in chick embryos. Development 124:805-816.

Rachel RA, Dolen G, Hayes NL, Lu A, Erskine L, Nowakowski RS, Mason CA (2002) Spatiotemporal features of early neuronogenesis differ in wildtype and albino mouse retina. J Neurosci 22:4249-4263.

Raible F, Brand M (2001) Tight transcriptional control of the ETS domain factors Erm and Pea3 by Fgf signaling during early zebrafish development. Mech Dev 107:105-117.

Roberts MR, Srinivas M, Forrest D, Morreale de Escobar G, Reh TA (2006) Making the gradient: thyroid hormone regulates cone opsin expression in the developing mouse retina. Proc Natl Acad Sci U S A 103:6218-6223.

Roehl H, Nüsslein-Volhard C (2001) Zebrafish pea3 and erm are general targets of FGF8 signaling. Curr Biol 11:503-507.

Swindell EC, Bailey TJ, Loosli F, Liu C, Amaya-Manzanares F, Mahon KA Wittbrodt J, Jamrich M (2006) Rx-Cre, a tool for inactivation of gene expression in the developing retina. Genesis 44:361-363.

Taranova OV, Magness ST, Fagan BM, Wu Y, Surzenko N, Hutton SR, Pevny LH (2006) SOX2 is a dose-dependent regulator of retinal neural progenitor competence. Genes Dev 20:1187-1202.

Tuveson DA, Shaw AT, Willis NA, Silver DP, Jackson EL, Chang S, Mercer KL, Grochow R, Hock H, Crowley D, Hingorani SR, Zaks T, King C, Jacobetz MA, Wang L, Bronson RT, Orkin SH, DePinho RA, Jacks T (2004) Endogenous oncogenic K-ras(G12D) stimulates proliferation and widespread neoplastic and developmental defects. Cancer Cell 5:375-387.

Van Vactor D, O'Reilly AM, Neel BG (1998) Genetic analysis of protein tyrosine phosphatases. Curr Opin Genet Dev 8:112-126.

Vinothkumar S, Rastegar S, Takamiya M, Ertzer R, Strähle U (2008) Sequential and cooperative action of Fgfs and Shh in the zebrafish retina. Dev Biol 314:200-214.

Wang SW, Kim BS, Ding K, Wang H, Sun D, Johnson RL, Klein WH, Gan L (2001) Requirement for math5 in the development of retinal ganglion cells. Genes Dev 15:24-29.

Wright TJ, Ladher R, McWhirter J, Murre C, Schoenwolf GC, Mansour SL (2004) Mouse FGF15 is the ortholog of human and chick FGF19, but is not uniquely required for otic induction. Dev Biol 269:264-275.

Zhang EE, Chapeau E, Hagihara K, Feng GS (2004) Neuronal Shp2 tyrosine phosphatase controls energy balance and metabolism. Proc Natl Acad Sci U S A 101:16064-16069.

Zhang L, El-Hodiri HM, Ma HF, Zhang X, Servetnick M, Wensel TG, Jamrich M (2003) Targeted expression of the dominant-negative FGFR4a in the eye using Xrx1A regulatory sequences interferes with normal retinal development. Development 130:4177-4186.

Zhao S, Thornquist SC, Barnstable CJ (1995) In vitro transdifferentiation of embryonic rat retinal pigment epithelium to neural retina. Brain Res 677:300-310

Zhao S, Hung FC, Colvin JS, White A, Dai W, Lovicu FJ, Ornitz DM, Overbeek PA (2001) Patterning the optic neuroepithelium by FGF signaling and Ras activation. Development 128:5051-5060. 